\title{
Three Eras of Indonesian Arts Diplomacy
}

\author{
Matthew Isaac Cohen \\ University of London \\ matthew.cohen@rhul.ac.uk
}

\begin{abstract}
Sukarno took a personal interest in using the arts for presenting Indonesia in a positive light. He oversaw cultural missions abroad and produced 'cultural events' that showed off his grace and charisma on the dance floor to overseas guests. While Soeharto showed little interest in the arts, new modes of arts diplomacy flourished during the New Order-scholarships for foreigners to study arts, artists in residence at Indonesian embassies, large-scale festivals aiming to facilitate artistic exchange and encourage foreign investments, to name but a few. In Indonesia today, arts diplomacy is represented by its own sub-directorate in the Ministry of Education and Culture. Indonesia is promoting itself through collaborations between Indonesian governmental agencies and professional, international producing bodies, galleries, and festivals. Cultural Houses are being built in key cities abroad, along with a nationwide platform for international festivals, Indonesiana. 'Indonesianists', including foreign academics and students of the arts, are being recruited to promote Indonesia abroad.
\end{abstract}

\section{Keywords}

arts diplomacy - cultural diplomacy - soft power - Indonesia - Mochtar Kusumaatmadja - Sukarno

\section{Three Eras of Indonesian Arts Diplomacy}

Arts diplomacy is arguably one of the oldest forms of diplomacy and international relations. Anthropologist and historian Johannes Fabian (1999) ponders how time and again in 'first contact' scenarios hosts and guests feel compelled to present dances, songs, and other arts to communicate something essen-

(C) MATTHEW ISAAC COHEN, 2019 | DOI:10.1163/22134379-17502022

This is an open access article distributed under the terms of the prevailing CC-BY-NC license at the time of publication. 
tial about their respective societies. Theatre historian Christopher Balme further details episodes when European sailors played trumpets and danced in response to the dances and conch-shell welcomes or warnings given to the visitors to Pacific islands as the first stage of exchange, culminating with 'the mimesis of the other, as both Polynesians and Europeans adopt each others' clothes and performance' (Balme 2007:20). This trajectory-from spectacular displays that hail the other while locating the self, to mimesis, hybridity, and exchange-is traced time and again in histories of intercultural encounter.

In Asian cultural history, we can recognize many instances of arts and cultural diplomacy long before terms for it existed. In pre-modern times, for example, the Okinawan classical dance-theatre kumiodori (ensemble dance) was created in 1719 by the minister of dance of the Ryūkyū Kingdom to entertain the Chinese envoy overseeing the installation of Ryūkyü's new king; the form catered explicitly to Chinese taste by incorporating noh and Chinese aesthetic influences (Suzuki 2016). The Sejarah Melayu (Malay chronicles), possibly written in seventeenth-century Johor, narrates a diplomatic crisis caused by a comically unequal artistic exchange between Majapahit and Malaka, in which the Javanese kingdom aimed to awe Malaka with its spectacular courtly arts while the Malay sultanate responded with an insulting children's game (C. Brown 1952:80-1; Cohen and Noszlopy 2010:4-6).

The most celebrated Asian arts practitioners of the early twentieth century were implicated in, or conceptualized projects in, arts diplomacy. Chinese opera performer Mei Lanfang's New York tour in 1930 was a carefully orchestrated venture to impress America's cultural capital with the sophistication of Chinese culture and overcome negative stereotypes of China propagated in popular media such as Hollywood films (Goldstein 1999). Korean dancer Choe Seung-hui's tours to the United States later in the 1930s and early 40s (performing under her Japanese name Sai Shoki) promoted Japanese conceptions of pan-Asianism; Choe's masterful embodiment of a variety of Asian dance styles justified an expansionistic imperial project, as it demonstrated the continuity of Asian traditions and the mutability of the Asian body (Park 2006). Rabindranath Tagore's numerous overseas tours, which often included poetry recitations and musical concerts, could likewise be seen as a form of arts diplomacy, promoting as they did his brand of 'cosmopolitan nationalism' (Williams 2007).

Despite the long history, the academic study of this area of applied arts practice has only really emerged in recent years, snapping into focus with David Caute's study of the Cold War 'struggle for cultural supremacy' waged between the Eastern and Western blocs (Caute 2003). There has been a growing number of studies of arts diplomacy in Asian contexts since (see, for instance, Lindsay 
2012; Thornbury 2013; Wilcox 2017), but the field remains under-researched and under-theorized, just as foreign affairs ministries in practice tend to undervalue the arts' efficacy (J. Brown 2006).

Therefore, it is necessary to establish some definitions. Arts diplomacy can be described as an aspect or subfield of cultural diplomacy involving the strategic management and deployment of the arts in order for a nation or other political entity (such as a region or intergovernmental organization) to accrue economic or political benefits and cultivate soft power internationally. Arts diplomacy can take diverse forms. Examples include: touring productions or exhibitions abroad; artistic exchanges; bespoke performances for dignitaries or VIP guests visiting a country; performing-arts markets; participation in, or the hosting of, international festivals, biennales, or expos; translated literature or subtitled films; lecture tours by artists or arts scholars; websites promoting national arts; endowed posts related to the arts in overseas institutions (a professorship, artist-in-residency, or curatorial post); gifts of equipment for making art (a noh stage or a set of classical Thai musical instruments); studentships or fellowships to attract foreign students and researchers to study the arts; sponsorship of overseas museums; or support of cultural centres abroad, along the lines of the Alliance Française.

The aims behind such initiatives, stated or unstated, typically are image improvement or enhancement; attracting business investment and tourism; and/or encouraging foreign consumers to purchase export goods (including, but not limited to, arts products). Often there are other, more ill-defined goals in such 'charm offensives', such as the generation of good will, mutual understanding, or neighbourly relations. While arts diplomacy is generally a state project it can also be a private initiative (such as the Hyundai Commission at Tate Modern's Turbine Hall), or involve a combination of private and state agencies.

Practitioners of arts diplomacy usually intend to make some sort of argument about a region or country through the arts, but arguments might not be stated explicitly. Arguments might also fail to be coherent or consistent with government policy. And regardless of cogency, it does not follow that an argument will be adequately expressed by the agents entrusted by the state, nor that it is apprehended by the target audience, nor that they will accept its validity (Ang, Raj, and Mar 2015). So, to cite a well-known example, the 1950s Jazz Ambassadors programme of the us Department of State sent America's leading jazz musicians-including Dizzy Gillespie, Louis Armstrong, Duke Ellington, Thelonious Monk, Benny Goodman, Miles Davis, and Dave Brubeck—on overseas tours to promote America's commitment to freedom. But, particularly in informal discussions with the jazz aficionados they encountered worldwide, 
America's jazz ambassadors spoke their own minds about American racial tensions, the experience of segregation, and Jim Crow legislation (von Eschen 2006). Whether their touring elevated America's image overseas at the end of the day is thus disputable.

Today among Asian countries it is South Korea and Japan that excel in the field of arts diplomacy - their efforts stand as models not only for Asia, but also for other countries around the world. Chinese investments in arts diplomacy, though substantial, with more than 5 oo Confucius Institutes worldwide (Yuan, Guo, and Zhu 2016), remain controversial. Other Asian countries, including Indonesia, are playing catch-up with these East Asian powerhouses.

Indonesia benefits from ready international recognition of some of its traditional arts (such as gamelan and batik), but also sometimes struggles for respect due to Orientalist stereotypes of exoticism, fixity, and backwardness; association with disaster and terrorism; poor understanding of Indonesia's geography and history; the relatively small number of Indonesians living overseas; and limited expertise in international cultural brokerage. In this article, I propose to take stock of Indonesia's arts diplomacy since independence in order to assess the strategies and tactics of managing culture over three political eras. This exercise has a reflexive edge to it - for like many Indonesia experts, I have been involved or implicated in numerous forms of Indonesian arts diplomacy over the years, sometimes as a beneficiary of funding, sometimes as a member of the target audience, sometimes as a surrogate arts diplomat myself.

\section{The Beginnings of Arts Diplomacy in Indonesia}

Indonesia has yoked the arts to diplomacy since the birth of the Republic. Like other postcolonial nations, Indonesia was burdened with Orientalist images, such as being indolent and profligate, and having mystical tendencies, which had been projected and imposed upon it by its former colonizer, the Netherlands. The new nation-state turned to the arts to assert independence and autonomy. Drawing on Charles Taylor's concept of the 'politics of recognition' (Taylor 1994), we can understand Indonesian arts diplomacy initially as a channel for Indonesians to argue that their culture was of equal value to other cultures. Ultimately, this has led to what Taylor (after Gadamer) has called a 'fusion of horizons', with new vocabularies of comparison being created as Indonesian arts practices disseminate globally.

Before independence was declared, in 1945, Indonesian artists had participated in Dutch-managed cultural delegations to world fairs and international exhibitions, promoting export productions like tea and serving to validate 
Dutch arguments for colonial benevolence (Bloembergen 2006). Starting in the 1910s, Indonesian students in the Netherlands had also banded together to perform 'Indies evenings' with samplings of different ethnic arts. These public events aimed to demonstrate the sophistication of their cultures and counter colonialist claims of backwardness (Cohen 2010, 2013). ${ }^{1}$ The self-funded world tour of Devi Dja and her 'Bali-Java dancers' in the late 1930s and early 1940s was represented by a Marxist Indonesian critic as a challenge to stereotypes of Indonesia as a 'negeri karet' (rubber nation) capable only of supplying raw materials for world markets and filled with pliable 'perawan Bali' (Balinese maidens) available for sexual exploitation (Bogk, quoted in Cohen 2010:202).

During the first months of the Japanese occupation (1942-1945), local organizing committees sprang up spontaneously around the archipelago to assemble cultural evenings to present local and cosmopolitan arts as a means to introduce themselves to Japanese officials and soldiers. An arts school named Sekolah Tonil was formed in Jakarta in 1942 with the express aim of creating variety shows for entertaining Japanese military and civilian elites (as well as disseminating propaganda). Established Indonesian arts organizations such as the Yogyakarta dance school Kridha Beksa Wirama were also pressed into performing for visiting Japanese dignitaries (Cohen 2016:175-233).

Skills built up through creating propaganda art under the Japanese provided a basis for using art to tell the world about independent Indonesia. To promote the cause of the Revolution, the Indonesian Information Office was set up in New York. This office published articles and pamphlets about Indonesian arts and organized dance performances to demonstrate the vital, autonomous national culture and counteract Dutch propaganda that Indonesia remained a Japanese puppet (Cohen 2016:243-4). During Sukarno's presidency (19491965), the arts assumed a prominent role in representing Indonesia to the world. This was in part because of Sukarno's personal interest in the arts, but also due to the convictions of a generation of artists and intellectuals, under the influence of Arnold Toynbee's philosophy of history, who were determined that Indonesia make a contribution to what Toynbee called 'world civilization'.

1 Similar cultural evenings with samplings or condensed versions of different arts had been performed in the first decade of the twentieth century by students of sTOVIA, the medical training academy that was Indonesia's first institution of higher education for 'natives'. Some of these evenings took place at European venues and thus implicitly addressed Europeans. For a report on one of these early cultural evenings, a performance in the schouwburg (Europeanstyle theatre) of Batavia (present-day Jakarta) by Javanese medical students for a mostly European audience, see 'De feesten', Het Nieuws van den Dag voor Nederlandsch-Indië, 4-51909. 
One of the earlier post-independence efforts in arts diplomacy was the Dancers of Bali world tour of 1952-1953 (Coast 1953). This tour took dancers and gamelan musicians from the village of Peliatan to the great cities of the world. It emphasized virtuosity, with lightning-fast changes in tempo and dynamics, flashy costumes, elaborate stage lighting, and a revue-style format familiar to cosmopolitan audiences and easily adaptable to television. The 12-year-old dancer Raka Rasmini was touted as a star (Noszlopy 2014). The tour was produced by the English self-confessed balletomane John Coast and recapitulated some of the same programme items and artists that featured in the Paris Colonial Exhibition of 1931. The tour's neo-colonialism was the subject of debate in Jakarta. Coast was excised from the group midway through the tour. Thereafter, high-level 'cultural missions' mostly featured a mix of performers representing different ethnic groups of Indonesia in order to showcase Indonesia's cultural diversity.

These productions, with multi-ethnic casts of performers, were sent out to countries around the world during the 195 os and 6os. In Jennifer Lindsay's incisive analysis, these missions were 'an expression of [...] national confidence and pride. [...] Cultural tours and exchanges were a way that nations talked to each other, eyed one another, and, through displaying what they were to various others, came to know that for themselves' (Lindsay 2012:195, 207). The compilation and juxtaposition of different ethnic arts and modern, cosmopolitan arts, such as national songs and modern dances, in a potpourri format, Lindsay (2012:207) writes, 'portrayed Indonesian culture as part of a new, young and moving world, not (as in the colonial world fairs) in contrast to it'. According to Edi Setyawati, a participant in some of these tours who went on to be the director general for culture in the Departemen Pendidikan dan Kebudayaan (Department of Education and Culture) under Presidents Soeharto and Habibie (1993-1999), these cultural missions played an important role for the artists themselves, one which was perhaps more vital than any message conveyed to outsiders. Through preparing for tours and touring together, artists from around the archipelago could become 'more aware of differences between art styles', exchange 'skills and ideas', gain 'respect for each other's region', and feel more Indonesian as a result (Setyawati, quoted in Lindsay 2012:214). ${ }^{2}$

2 As Lindsay (2012:196-7) notes: 'Apart from the presidential-level missions and other less prestigious official cultural missions, there were also at least four other kinds of tours by Indonesian performers representing their country: cultural missions that were not curated by Indonesian government authorities but were given government assistance and official sanction (for instance a 196o tour to Malaya of popular radio stars); performers who toured as part of other larger events, particularly the biennial socialist World Youth Festivals organized by 
Sukarno's most lasting contribution to arts diplomacy arguably was the creation of the dance-drama known as the Ramayana Ballet. This involved the construction of a 500-foot-long open-air stage against the backdrop of the 1200year-old Prambanan temple complex, which illustrates the Ramayana epic in its reliefs and was illuminated during performances by spotlights. The entire Ramayana epic was told without dialogue or narration over six nights by a cast of some 300 dancers and 6o accompanying gamelan musicians. Three planeloads of ambassadors and other guests accompanied Sukarno to the ballet's debut in $1961 .{ }^{3}$ The sendratari form was considered a radical innovation at the time - and was quite controversial in traditional Javanese art circles in particular-but has since become quite standard around Indonesia, and is a preferred vehicle for narrating stories about local history.

Another important form of arts diplomacy under Sukarno were performances created for visiting dignitaries. All of Sukarno's diplomatic projects, including the monumental 1955 Asia-Africa Conference in Bandung, were infused with his charismatic personality and theatrical flair (Shimazu 2014). But the private functions Sukarno staged during the 1950s and 6os, typically displaying Javanese dance for those visiting him in the presidential mansions in Jakarta and Bogor, or Balinese dance for those visiting his Balinese palace in Tampaksiring, enabled him to show his great charm at an intimate distance. These performances featured beautiful young artists-some of whom were reportedly Sukarno's sexual partners—and often concluded with social dancing between the international vips and Indonesian dancers. These occasions aimed to show off Sukarno's virility and social graces, generating fraternal relations between the Indonesian hosts and visitors, while simultaneously demonstrating the superb talents of Indonesia's best musicians and dancers. These 'cultural events', as they were referred to in diplomatic circles, were both cosmopolitan in flavour and easily accessible to international guests (dances were short and flashy, and tended to be non-narrative) and at the same time built upon long-established Indonesian traditions of social dancing, which, as described by Henry Spiller (2010), are means to express masculine prowess, maintain social hierarchy, and generate homosocial relations among men. Sukarno favoured simple folk forms, such as the Moluccan dance tari lenso, as these facilitated participation by non-trained dancers.

the World Federation of Democratic Youth; LE KRA-sponsored cultural delegations; and tours of Indonesians who were based overseas, particularly students and embassy staff (one striking aspect of the time is that Indonesian students abroad were all expected to be able to sing and dance and thus represent their country in cultural performances).'

3 'Indonesia begins a dance festival', New York Times, 10-9-1961. 
A Russian newsreel from circa 196o shows Sukarno dancing at a state occasion in his signature military uniform and black peci cap. ${ }^{4}$ He moves confidently with sweeping, punctuated arm gestures and a beaming smile. His head swivels constantly, and in this way not only recognizes his dance partner, a young woman in traditional dress, but also others of importance in the hall. He is the embodiment of masculine bravado, successfully 'jockeying for power within a patriarchal system' (Spiller 2010:165).

When Yugoslavia's president Josip Broz Tito moored his ocean-going yacht off the coast of Bali at the end of 1958, he was greeted on shore by 100 Balinese dancers-described by Time magazine as 'barefoot maidens in sarongs' — who danced in bare feet on the rough streets of Denpasar and presented Tito with a 'silver bowl filled with flowers'. After a day of touring Bali with Sukarno, Tito and his delegation were whisked off to Tampaksiring for a night of music and dancing in a 'gala New Year's Eve party' that went on until 7 a.m.- the champagne and slivovitz were on Tito. ${ }^{5}$ The great Balinese dancer Ayu Bulantrisna Djelantik—then all of 11 years old — recollected being carried on the shoulders of Tito's sailors (Forbes 2007:65).

Tito and Sukarno embraced and kissed at midnight-a mode of homosociality that homophobic American media questioned and even mocked. In contrast, Soviet premier Nikita Khrushchev was nonplussed by what he called Sukarno's 'theatricality'. This led to a widely reported diplomatic incident during Khrushchev's 196o visit to Indonesia. Khrushchev was not immune to the charms of arts for diplomacy. In his memoirs, he speaks approvingly of the artistic talents of Hurustiati Subandrio, who sometimes sung 'Russian songs, and sang them well' at official receptions at the Indonesian embassy when her husband Subandrio was ambassador to Moscow (1954-1956). He adds to this that 'this couple, the ambassador and his wife, enjoyed the great respect of the Soviet leadership. All of us' (Khrushchev 2013:791). Despite this, he saw Sukarno's theatricality as 'a negative feature'. Sukarno's most pressing request during Krushchev's 1960 visit was for the USSR to fund the construction of a stadium for the 1962 Asian Games. Khrushchev perceived this as a vanity project for Sukarno, as he understood that the main function of the stadium after the Games was to be 'a big stage' for Sukarno's rallies. Such an extravagance was not

4 'Bung Karno menari', https://youtu.be/6L8Y2DoEQJM (accessed 12-7-2018). Many thanks to Dr Ayu Bulantrisna Djelantik for providing this link.

5 'Southeast Asia: Tito's travels', Time, 19-1-1959; Bernard Kalb, 'Sukarno shows Tito Bali sights: Yugoslav leader showered with flowers on his last full day in Indonesia', New York Times, 1-11959 . 
befitting a 'backward country' that was only starting to develop 'real industry' (Khrushchev 2013:787-8).

In Time magazine's coverage of Khrushchev's 196o Southeast Asia tour it was reported that, 'Khrushchev hurt President Sukarno's pride in his country's culture by walking out halfway through a Balinese dance. ${ }^{6}$ Another source had it that in the midst of the performance Khrushchev quipped, "This is all very nice but it does not bring any foreign currency into your country!" Sukarno, who had been already shocked by similar philistine remarks from his bulky guest earlier in the tour, immediately ordered the dancers to stop!' (Dhaimeler 2007:93).

Khrushchev's own telling of his cultural faux pas is more sober. He recounts that he had already endured one long evening of dancing on the same 1960 visit, though he was 'absolutely not a dancing person', with little terpsichorean interest and even less practical aptitude. Faced with a repeat of the same sort of programme-a musical introduction, solo dance numbers, followed by participatory dances in which Sukarno took turns dancing 'with all the young women ... [while] joking and making witty conversation'-Khrushchev begged to take his leave early. 'Sukarno was amazed: "What? That's impossible. The girls will be insulted. Do me a favour and stay." But Khrushchev was adamant. The next day, realizing he had made a strategic error, Khrushchev made amends by introducing Sukarno, who had caught a cold (perhaps from his excessive night-time dancing), to a young ear, nose, and throat specialist who was part of Krushchev's delegation. Not only was the doctor attractive, she also was a good dancer, and at that night's 'cultural event' Sukarno spent much time dancing with her. Khrushchev relates that 'the next morning I asked her: "How did you like the president?" She gave me a sly smile and replied that he was quite the cheerful fellow' (Khrushchev 2013:801-2).

While the history of international relations has focused on declarations, pronouncements, and treatises, the emotional labour of participatory performances and the social and sexual solidarities that fructify from them are often the glue that binds individuals officially charged with representing state interests, and through them the countries they represent. Sukarno's surplus of charisma, personal charm, hypermasculinity, and artistic flair meant that during his regime Indonesia played a larger role on the diplomatic stage than might have been expected.

6 'Communists: Second time around', Time, 14-3-196o. 
Sukarno's successor, President Soeharto, had little personal interest in the arts. He rarely entertained dignitaries with lavish 'cultural events' of the sort routinely organized by Sukarno. While Sukarno regularly sponsored wayang puppet theatre performances at the presidential palace in Bogor, and reportedly collaborated with puppeteers to insert policy messages and veiled critiques of government officials present (Pink 1996), in contrast, Soeharto rarely if ever attended an all-night wayang performance during his three decades in office - though as a good Javanist Soeharto made frequent reference to the symbols and figures and forms of wayang. 'Presidential-level' cultural missions likewise effectively ceased after Soeharto's assumption of power, though less high-profile tours were staged. ${ }^{7}$

New modes of arts diplomacy, however, were developed under Soeharto. The Darmasiswa scholarship scheme began in 1974 'to promote and increase the interest in the language and culture of Indonesia among the youth of other countries. It has also been designed to provide stronger cultural links and understanding among participating countries.' 8 Initially only catering to students from other ASEAN countries, which offered similar exchanges for Indonesians, currently more than 8 o countries worldwide participate in this scholarship programme. This has been a primary mode for foreigners to train in traditional gamelan, dance, puppetry, and crafts in Indonesian tertiary arts institutions. Many former Darmasiswa students return to their countries of origin to become teachers and performers, acting as unofficial cultural ambassadors for Indonesia.

During the Sukarno period, embassy staff-and typically their spouses and children as well-were often devoted amateur performers of regional arts, who were called upon to sing folksongs or perform dances at embassy func-

7 Two of the more consequential cultural missions for the development of gamelan in the United States were those undertaken by the Budaya Troupe, which toured programmes of Javanese, Sundanese, and Balinese dance, music, and puppetry to theatres and university campuses in 1969 and 1971 under the joint sponsorship of the Indonesian government and the American Society for Eastern Arts. The troupe's leader, the gamelan musician and composer Wasitodiningrat (known by intimates as 'Pak Cokro'), was appointed to a post at the California Institute for the Arts at the conclusion of the 1971 tour, where he taught until 1993. Wasitodiningrat was Java's leading gamelan composer-his works included arranging music for the original Ramayana Ballet - and maintained close links to Indonesia throughout his American tenure. More than any Javanese artist he was responsible for introducing a generation of Americans to gamelan and Javanese arts and artists more generally (Wenten 1996).

8 http://darmasiswa.kemdikbud.go.id/about-us-2/, accessed 13-o6-2o19. 
tions or local cultural festivals. But starting in the 1970s it became policy to appoint artists - mostly gamelan musicians and dancers - to key embassies where there was local interest in studying Indonesian arts. These embassy employees did office work in the day and taught community gamelan groups and performed in the evenings. The Javanese gamelan musician and dancer F.X. Suhardi Djojoprasetyo worked in the embassy in The Hague starting from 1975, teaching and performing with groups in the embassy and around the Netherlands, and continued to teach and perform even after his official retirement. Two Javanese artists appointed in Australia, Poedijono in Melbourne and Soegito Hardjodikoro in Canberra, were the mainstays of Javanese classical arts in Australia for decades. In the United Kingdom in the 199os, the embassy in London hosted a string of performing artists from Sekolah Tinggi Seni Indonesia Surakarta (Surakarta's College of Traditional Indonesian Arts), who came in two-year stints to do office work and participate in community gamelan groups-including dancers Sunarno Purwolelono and Didik Bambang Wahyudi. The embassy was aware that most gamelan groups in Britain play in the Surakarta (or Solo) style, so it brought teachers who espoused this regional performance style (Lopez y Royo 2008).

A major push for arts diplomacy came in the 1980 os via Mochtar Kusumaatmadja, Indonesia's foreign minister between 1978 and 1988. Kusumaatmadja was responsible for formulating, in 1983, the notion of cultural diplomacy (diplomasi budaya or diplomasi kebudayaan). An American-trained legal scholar specializing in maritime law, Kusumaatmadja is best remembered for his conceptualizing of the notion of the archipelagic state, signed into international law by a United Nations convention in 1982. This established that the exclusive sovereignty of a nation composed of a group of islands extended to the waters between them. Kusumaatmadja's understanding of cultural diplomacy was likewise formulated in terms of national interests. He was less interested in 'mutual understanding' or 'good will' than in the strategic goal of membangun citra Indonesia di luar negeri-which might be translated as either 'raising the image of Indonesia abroad' or 'developing a portrait of Indonesia internationally' (Kusuma-Atmadja 1987). ${ }^{9}$

To critics who accused him of betraying the postcolonial principle of diplomasi perjuangan (revolutionary diplomacy), the key term of reference for Indonesia's foreign service since 1954, Kusumaatmadja answered that cultural

9 The verb membangun, which carries the double meaning of 'get up, wake up, rise (from a chair, sleep, etc.)' as well as build, construct and develop, is from the same root (bangun) as the Indonesian term for 'development' (pembangunan) (Stevens and Schmidgall-Tellings 2004:88-9). 
diplomacy is a form of revolutionary diplomacy: the continuing vitality of Indonesia's arts and culture demonstrates that Indonesia might have been subject to Dutch colonialism for centuries, but this never 'extinguished the vitality of the people'. Glossing the famous Toynbee-inspired 1950 credo of the Jakartan art association Gelanggang ('We are the legitimate heirs to world culture, and we are furthering this culture in our own way'), Kusumaatmadja proclaimed that ' $[t]$ hough a newly independent nation we are a cultured people who can offer contributions to various aspects of society, not only in the field of arts and culture, but also in the field of other aspects of human society'.10

While Kusumaatmadja's rhetoric was of selfless contributions to the world, it is not hard to see his conception of cultural diplomacy as a Soeharto-era development project that aimed to build a cultural superstructure to enhance credibility and trust in Indonesia for the sake of attracting overseas investment in physical infrastructure and industry, tourism, and export goods. Significantly, though Kusumaatmadja focused on issues of sovereignty in maritime law, his cultural-diplomatic efforts were anything but proprietary. Intellectual property law was a low priority in Indonesia in the 1980s: the country at that time 'had a reputation as one of the worst infringers of intellectual property rights in the world' (Rosser 2001:149). Instead, like the preceding Darmasiswa programme and the project to seed local Indonesian arts in the Netherlands, Australia, and other countries by providing embassy-based teachers, the focus was on sharing Indonesian arts with the world, and opening up access to them in order to develop Indonesia's reputation for civility, thus counteracting the negative associations of Indonesia with militarism, the weak rule of law, and crony capitalism. Cultural diplomacy was thus intended by Kusumaatmadja to complement political and economic diplomacy. Flush with oil money earned from the increase in oil export revenues in the 1970s, Indonesia was well positioned to invest in disseminating its culture abroad and to compile evidence that its arts and culture were already influential internationally.

Kusumaatmadja's major innovation was to formulate and implement Indonesia-focused cultural events carried out in conjunction with international agencies and institutions or within expo or biennale frameworks. At Expo 86, a world fair held in Vancouver, Canada, the Indonesian government sponsored what was billed as the First International Gamelan Festival, a three-day celebration with 11 ensembles from the United States, Japan, Germany, Canada, and Indonesia performing both traditional and contemporary compositions,

10 Kusumaatmadja, quoted in Chisa Yukihira, 'Sejarah diplomasi Indonesia: Metoda diplomasi', 5-1-2015. http://diplomacyofindonesia.blogspot.com/2015/o1/metoda-diplomasi .html, accessed 13-06-2019. 
and a symposium with some of the most renowned international gamelan experts as speakers (Chalmers 1986). The Indonesian delegation under the direction of post-traditional choreographer Sardono W. Kusumo (one of the original sendratari dancers), showed a versatility in styles: players were equally adept at traditional numbers, tradition-based 'new compositions', and experimental compositions (the sort of work later to be referred to as kontemporer, or 'contemporary'). This mix struck a great cord with the non-Indonesian artists and experts present, who up until then had treated Indonesia largely as a root source rather than a coeval society in which the arts were continually evolving. North Americans were stimulated by this event to conduct research on Indonesian contemporary arts and enter into collaborations with innovative Indonesian artists with renewed enthusiasm for tradition.

Expo 86 was a means not only to teach North American audiences about contemporary developments in Indonesian arts, but also served to validate North American gamelan practices. In his speech at the gamelan festival, Indonesia's minister of finance J.B. Sumarlin singled out ethnomusicologist Mantle Hood, who had introduced gamelan to American university campuses in the 1950s as a way of learning about a foreign musical culture through practice, for particular praise. He joked that if Hood was in Indonesia he would be known not as Professor Mantle Hood but as Ki Mantle Hood ('Ki' being a title of respect granted to revered teachers, religious figures, and artists). Hood seems to have taken this small joke seriously and forthwith prefaced his name with 'Ki' in publications, public speeches, and on other occasions (Spiller 2015:1834).

The gamelan festival's programme reported how Indonesia was pleased regarding 'the way in which gamelan has become an international art form and a powerful influence on contemporary music' and expressed the hope that the event would 'encourage the development of gamelan as an international musical language and a vehicle for human understanding and creativity' (Chalmers 1986:13). American gamelan instructor Jody Diamond, in an editorial piece, expounded that the festival 'put to rest' an ideological division between gamelan as practised in and outside of Indonesia, arguing that "international gamelan" unites all who have been inspired by the traditions of Indonesia' (Diamond 1986:1). In this way, gamelan was figured as both Indonesian and 'international', local and cosmopolitan.

Other acts of arts diplomacy under Kusumaatmadja's watch met with less success. British anthropologist Felicia Hughes-Freeland (1989) gave a scathing report of two government-sponsored cultural events in London in June 1989 - an exhibition of Asmat art at the Commonwealth Institute and associated events, and a dance performance by a troupe from the Mangkunegaran 
court at the Institute of Education, University of London. The former was intended to demonstrate Indonesian concern and benevolence towards a part of Indonesia where there was grave apprehension about human rights abuses. The condescending treatment of Asmat culture in talks by Indonesian academics and the degrading treatment of the (non-professional) Asmat dancers grated on Hughes-Freeland and others (see also Sankey 1989).

The Mangkunegaran dance performance at the Institute of Education was also a travesty, in Hughes-Freeland's opinion. The court artists were forced to cut two items from their programme of gamelan and classical dance to accommodate the embassy's idea of staging a theatricalized wedding with embassy staff decked out in Javanese traditional dress. There was a cultural rationale for this, no doubt - most urban Indonesians in the late 1980s associated gamelan and classical dance with wedding receptions in air-conditioned halls, not royal courts - but it showed marked disrespect to the performers and high-handed treatment of a royal court that has been venerated in Java for the refinement of its aesthetics since the mid nineteenth century (see Cohen 2016:28-33). Hughes-Freeland (1989:5) points out that the audience at the Institute of Education was largely made up of 'old Indonesia hands unlikely to be taken in by the blandishments of "mock" weddings as acceptable signs of culture'. Indeed, a considerable degree of expertise was already in stock in London by 1989 due to the activities of the performing group English Gamelan Orchestra, educational programmes at the South Bank, and gamelan's embedding in universities (see Mendonça 2002). What could have been used as an opportunity for exchange and capacity-building was enacted instead as a non-participatory spectacle.

These cultural events in the late 1980 os were significant in their way, but in some sense they were only warm-ups for Kusumaatmadja's swan song in arts diplomacy - the Festival of Indonesia or KIAS (Kebudayaan Indonesia di Amerika Serikat, literally 'Indonesian Culture in the United States'). As Clifford Geertz (1991:30) proclaims in his round-up of KIAS, which took place in venues all over the United States during 1990-1991:

It sounds like a Barnum poster. Three hundred dancers and musicians! Fifty performances! Four major art exhibits! A hundred smaller ones! Puppet plays! Film series! Lectures ('The House That Wears Jewelry Like A Man', 'Footsteps In The Sea'), fashions, foods, textiles, photographs, flower arrangements, herbal medicines, maps, masks, videos, body music, navigation, folk life, mythology! Two-hundred and fifty events over eighteen months in fifty American cities: Washington and Houston, New York and Honolulu, De Kalb and Grand Rapids, St. Cloud and Upper Montclair! 
This festival was officially under the auspices of the foundation Yayasan Nusantara Jaya, a 'quasi-official body' (Geertz 1991:34) founded by Kusumaatmadja in 1984. While Kusumaatmadja had stepped down as foreign minister by 1988 he was able to use his networks to solicit donations from Indonesian and American business interests - with many of the latter already invested in doing business with and in Indonesia. The format of the festival - a year-long celebration across the country, profiling the diversity of Indonesian cultures past and present-followed the model of the $1985^{-1986}$ 'Year of India', and Ted Tanen, a state department official turned arts producer, who had produced this earlier festival, was brought on board as Kusumaatmadja's American counterpart. Individuals involved in past Indonesian arts diplomacy were recruited. Sardono, who had curated the international gamelan festival at Expo 86 with great success, was charged with curating the performing arts component of KIAS.

The festival's programming, in Geertz's (1991:34) analysis, was 'involved in creating a national persona out of clashing attitudes, cultural summary out of cultural swirl'. It simply was not possible to reconcile the Islamic with the Indic, tradition with contemporary, and so on, to create a coherent narrative of national culture. Against arguments for representing the Indonesian motto of Bhinneka tunggal ika (Unity in diversity), were those who clamoured to assert that what was needed was portraying how Indonesians resisted unityparticularly the domination of the Javanese over other ethnic groups. A major exhibition, Beyond the Java Seas, was added to the exhibition component and a grant from the Ford Foundation enabled academic conferences, workshops, and symposia on controversial topics such as Indonesian-Chinese, deforestation, gender in Indonesian society, and East Timor (Wallis 1994:275). Kusumaatmadja was initially resistant to including a critical element: 'We thought the festival was an occasion to create understanding and friendship, not to create conflict [...] This is about art, not politics.' But in the end he was swayed. 'To try to avoid controversy', he was told by Tanen, 'only creates more' (Wallis 1994:276).

Some commentators were impressed by the way in which Americans practising Indonesian arts, such as Balinese-trained puppeteer Larry Reed, were recognized in various ways, sometimes by being programmed as side events to the Indonesian-generated content, and admired how so much of the art work in performance and on display conflated and confused the categories of traditional and contemporary (Foley 1992; Gillitt 1991). Correspondences were identified that served to highlight mutuality, histories of exchange, and shared approaches and concerns. Indonesian performers and artists were consulted at every stage of the planning. So, for example, time needed for ritual offer- 
ings could be built into 'get-in' schedules and stage technicians were informed about ritual prohibitions and taboos-such as not stepping over gamelan instruments (Wasilewski 2017). Admirably, there were ample opportunities also built in for exchange between American and Indonesian artists. No small part of this was due to the efforts of Rachel Cooper, an American producer and gamelan player who was recruited away from teaching ESL in Jakarta to run the performing arts programme (known as the Festival of Indonesia in Performance), and who went on to a distinguished career as a producer at the Asia Society in New York City (Gillitt 2017).

Indonesian commentators trumpeted audience numbers, awards won, the variety of ethnic groups represented, and the amount of American funding that went into it (Warsito and Kartikasari 2007:129-61). Similarly, what impressed Clifford Geertz (1991:36) most about the festival was the festival itself-its scale, scope, and efficiency, the huge range of arts represented, 'the interpretive dilemmas of intercultural understanding that it forces us to reflect upon, and the social realities that, in spite of itself, it dramatizes'. My own reactions were similar. I reflected at length on my own puppetry practice and the complexities of presenting this art form outside Indonesia after watching the New York-based Indo puppeteer Tamara perform her idiosyncratic version of wayang kulit alongside the Court Arts exhibit at the Asia Society in the spring of 1991, and was troubled that the theatres of Yale University, where I was studying cultural anthropology, rejected festival overtures to book modern Indonesian drama troupes for inclusion in their seasons of plays. ${ }^{11}$

Since 1998, which marks the end of the New Order and the beginning of the Reformasi era, Indonesian arts diplomacy has waxed and waned in different countries globally, depending on Indonesian government policy, personal interests of ambassadors, the capacities of embassy staff, and offers made from overseas institutions for collaborating. Before 1998, classical and folk arts, particularly from Java and Bali, were prioritized over other arts in international exhibitions. But over the last decades, as Indonesia races to improve its ranking in the global creative economy, novelists, film makers, performance artists, contemporary visual artists, innovative theatre directors, and contemporary

11 A resistance to script-based drama was noted by two commentators on the festival as well (Foley 1991:18; Gillitt 1991:20). 
dancers are being actively promoted. Fashion designers and carnival costumes have featured heavily since the Jember Fashion Carnival captured worldwide attention a decade ago. Artists are being incentivized to create new work drawing on tradition in modern ways. Arguably there is less investment in the development of genres of art than in the practitioners who create them.

Earlier modes of arts diplomacy are still being practised, sometimes in enhanced form. As already noted, the Darmasiswa scholarship programme has expanded and the rehearsal halls and studios of arts schools are today full of students speaking Indonesian and English in Hungarian, Croatian, and Korean accents. This scholarship programme was supplemented, starting in 2003 with the Beasiswa Seni dan Budaya (Arts and Culture Scholarship), a three-month programme that places young people in their twenties from a number of countries with diplomatic ties to Indonesia for intensive study in arts centres in Bali, Sumatra, Kalimantan, Java, and Sulawesi (Warsito and Kartikasari 2007:199214). Different branches of the Indonesian government as well as private bodies have histories of donating sets of gamelan that go back at least to the 1980sthe Departemen Kehutanan (Indonesia's Ministry of Forestry) donated a set to the University of Oxford in 1985 called Kyai Madu Laras (Venerable Sweet Tuning) while the gamelan played at Expo 86 (Kyai Madu Sari, or Venerable Essence of Honey) was donated to Simon Fraser University. Such gifts, which can play a key role in seeding Indonesian arts not only in universities but also in surrounding communities, continue to be offered to this day. For example, the National Concert Hall in Ireland permanently houses a new gamelan named Kyai Jati Roso (Venerable Essence of Feeling), given by Sultan Hamengkubuwono x of Yogyakarta in 2014. ${ }^{12}$ Gamelan sets in embassies and consulates-formerly reserved for rehearsals by Indonesian embassy employees and their families and used for performances only at official embassy receptions-have been opened up to the use of community groups in locations including New York, Mexico City, Toronto, Perth, and Seoul. These ensembles are often the means by which Indonesian members can reconnect with 'home', non-Indonesians can learn more about Indonesia through music, and Indonesians and nonIndonesians can find common ground in an affinity group (McIntosh 2009).

Indonesian embassies have also played key roles in organizing cultural fairs in halls, tents, and outdoor locations. These events - which often combine the promotion of tourism and handicrafts; stalls for international businesses, such as Garuda Airlines; and food prepared and sold by local Indonesian restaur-

12 Kyai Madu Sari resides at Simon Fraser's School for the Contemporary Arts, while Kyai Madu Laras is in Oxford's Bate Collection of Musical Instruments. 


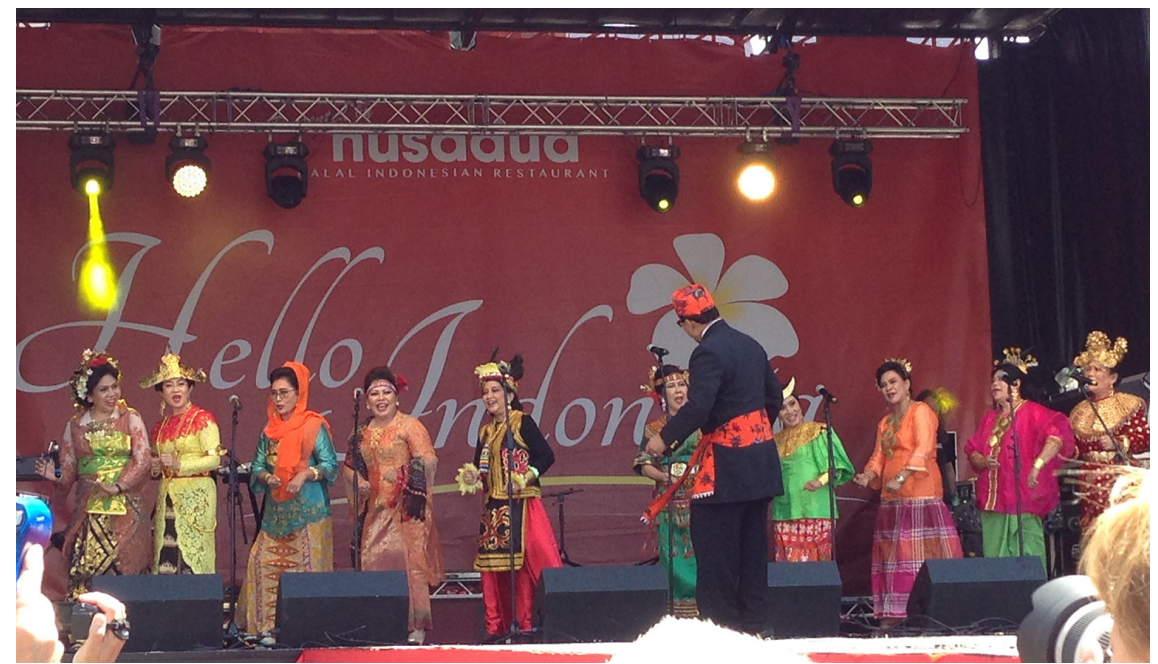

FIGURE 1 Friends and colleagues of Indonesian pop icon Titiek Puspa, all in traditional ethnic dress, sing chorally at Hello Indonesia, Trafalgar Square, London, 7 June 2015

ants and caterers with performances and workshops of Indonesian arts-have had mixed success. The Pasar Malam Indonesia has been staged annually since 2010 in the Malieveld park next to The Hague's central train station. It was established by Indonesia's ambassador to The Hague to stimulate cultural and business relations between the Netherlands and Indonesia. This fair was initially heavily criticized for being in competition with the annual Tong Tong Fair (formerly known as the Pasar Malam Besar), which occupies the same location on the Malieveld and has a similar format. Visitors also found the cultural programming of the Pasar Malam Indonesia to be stultifying, as artists were selected by Indonesian regional-government officials rather than a curator possessing awareness of Dutch tastes and norms. In response to such criticisms, in future events the organizers incorporated pop culture aspects, inviting for instance performances from the winners of Indonesian television talent competitions, which proved to be popular with visitors (Steijlen 2015:2167).

Performance curatorship has also been a problem for Indonesia-themed outdoor celebrations in London in recent years. Two large-scale events in Trafalgar Square under the rubric of Hello Indonesia (2014 and 2015) were followed by smaller events at Potters Field Park against the backdrop of the iconic Tower Bridge under the title Indonesia Weekend (2016-2018) (Figures 1 and 2).

These were produced with a combination of governmental and private sponsorship and management. At the 2015 edition of Hello Indonesia, for 


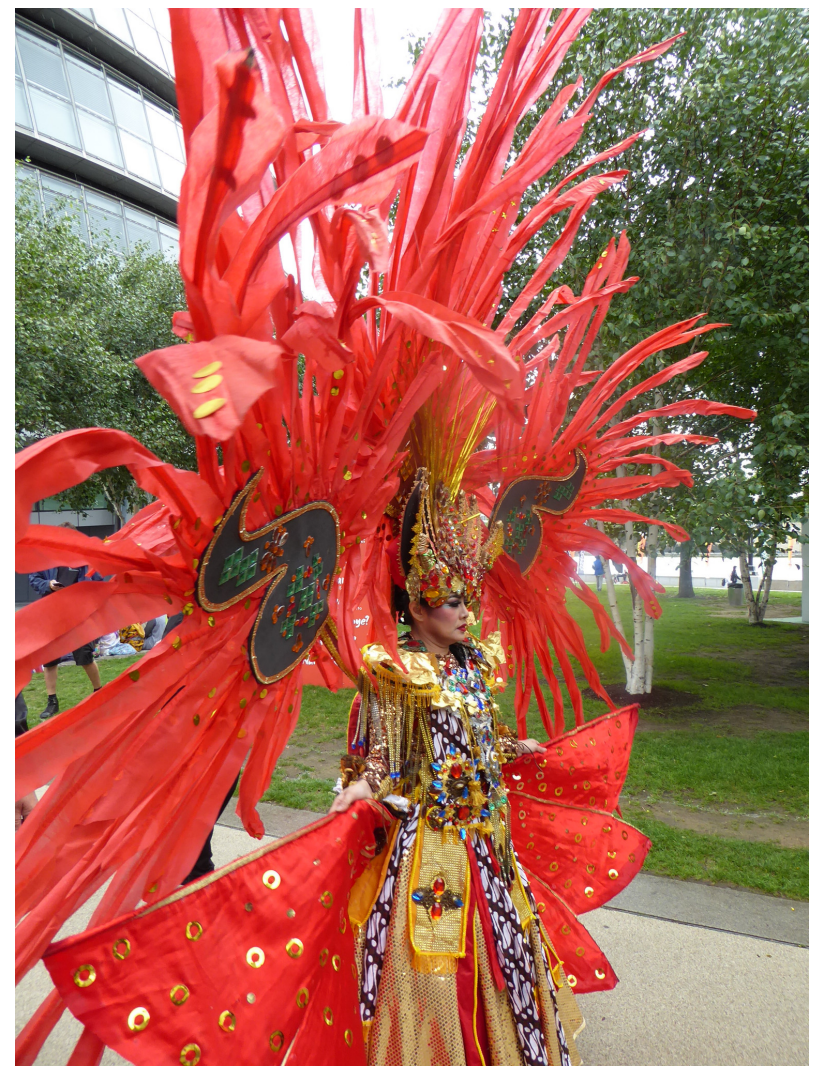

FIGURE 2

Indonesian carnival performer at Indonesia Weekend, Potter's Field, London, 22 July 2017

example, sponsored in large part by the London eatery Nusa Dua, curatorship was handed over to the aged pop idol Titiek Puspa (b. 1937), who brought along many amateur singers and dancers from her circle of Jakarta friends of a similar age-presumably because they could self-fund their way to London.

More successful have been collaborations between Indonesian governmental agencies and professional international producing bodies, galleries, and festivals. Noteworthy international events that have endeavoured to profile Indonesia through the arts in recent years include:

- the Indonesia Pavilion at Expo 2010 Shanghai China (2010)

- Indonesia Eye: Fantasies \& Realities at the Saatchi Gallery in London (2011)

- 'Performing Indonesia: A Conference and Festival of Music, Dance, and Drama', held at the Smithsonian Institution, a joint presentation of the Freer and Sackler Galleries and the Embassy of Indonesia (2013)

- the Indonesia Pavilion at the Venice Biennale $(2013,2015,2017)$

- Discover Indonesia, a festival produced by Cryptic in Glasgow and other British cities (2015) 
- Guest of Honour at the Frankfurt Book Fair (2015)

- guest country for the Europalia Arts Festival (2017-2018)

- Market Focus country at the London Book Fair (2019).

These events have been most meaningful and resonant when Indonesian art is allowed to speak both to local particularities and global issues, when strong curatorial concepts and the particularities of individual artworks comfortably co-exist, and when opportunities for exchange are allowed. Rather than dragging out what curator Alia Swastika calls 'nostalgic symbols' (Swastika, quoted in Ingham 2014) filtered through the lens of postcolonial exoticism, participating artists and companies are given the space and time to develop work in consultation and dialogue with curators and producers that is timely, passionate, and appropriate for the conditions of presentation.

For example, as the guest country for the latest edition of the Europalia Arts Festival (October 2017-January 2018), billed as 'the largest, the grandest, and the most prestigious cultural activity in Europe', an attempt was made to capture not only the current zeitgeist of Indonesia, but also to represent its past, drawing artists, academic experts, arts venues, and the public into a dialogue with lasting repercussions on how Indonesia is represented in Europe. The festival's website (https://europalia.eu/) attracted Indonesian sponsorship by listing on its website five key 'reasons why Indonesia should be proud to participate in [the] Europalia Arts Festival':

1. Indonesia is the first country from Southeast Asia to participate in [the] Europalia Arts Festival.

2. Known as the heart of Europe, Brussels, being the site for the Festival opening, is the right place to promote Indonesian culture and tourism to the world.

3. Witnessed by millions of eyes from all over Europe and the world.

4. A golden opportunity for Indonesia to showcase and introduce the whole culture of Indonesia.

5. A great momentum $[$ sic $]$ in promoting tourism, creative economy products, other products, and investment opportunities (accessed 15 August 2017).

The festival gave due attention to dynamics of tradition and modernity, postcolonial power dynamics, hybridity, gender, and identity politics, unearthing little-known artefacts and arts housed in European museums alongside the latest developments in Indonesian contemporary and post-traditional arts. Particular care was given to developing collaborative projects between European and Indonesian institutions, organizations, and artists, including extended residencies for Indonesian arts workers in Europe. Programming ranged from an exhibition on the history, since 1929, of Indonesian comic strips and comic 
books in a Brussels library to a new music concert by an ensemble directed by A.L. Suwardi, a Javanese composer, musician, and instrument builder who has taught many foreigners over the years, with gamelan-based instruments and compositions inspired by the Pythagorean theory of music of the spheres. Indonesian government officials I spoke to who attended Europalia were generally happy with the expert curatorship, professional management, and production of this massive, multi-sited event, though they complained that the location of the festival's core in Brussels meant that there was not the multiplier factor of festivals sited in larger European capitals.

In the 2010s, Indonesia's Ministry of Education and Culture has increasingly moved away from a top-down model of instigating and managing flashy arts-diplomacy events and is instead investing more in building sustainable partnerships and networks initiated and carried out in partnerships of external agencies, local governments, and artistic organizations and institutions in both Indonesia and abroad. An important development in this regard has been the formal recognition of what has been conceived as the Indonesian diaspora and the world-wide circle of Indonesianists. The Indonesian diaspora, as posited at the first Indonesian diaspora congress held in Los Angeles, California, in 2012, has been conceived in the broadest sense to include not only holders of Indonesian passports and people of Indonesian descent living abroad, but also non-Indonesians who 'have a caring attitude and spiritual ties to Indonesia' (memiliki kepedulian dan ikatan batin dengan Indonesia) (Supardi 2013:239). An explicit concern of this conference was to coordinate the cultivation of Indonesia's soft power through artistic activities (Supardi 2013:244).

Within the larger diasporic community, a sub-set of practitioners, organizers, and activists identified as 'Indonesianists' - including both academic experts and others with a 'keen interest in the country' - have been recognized as particularly significant diplomatic assets. ${ }^{13}$ We Indonesianists-for the Indonesian government positions me as one of them-are what Kwame Anthony Appiah has called 'cosmopolitan patriots', attached to the cultural particularities of Indonesia while at the same time able to take 'pleasure from the presence of other, different places that are home to other, different people' (Appiah 1997:618).

Those of us who have been active in Indonesian studies and arts practices over the decades are seeing our efforts being formally awarded and rewar-

13 Sheany, “'Indonesianists" are an important asset to diplomacy: Deputy FM', Jakarta Globe, 4-12-2017. 


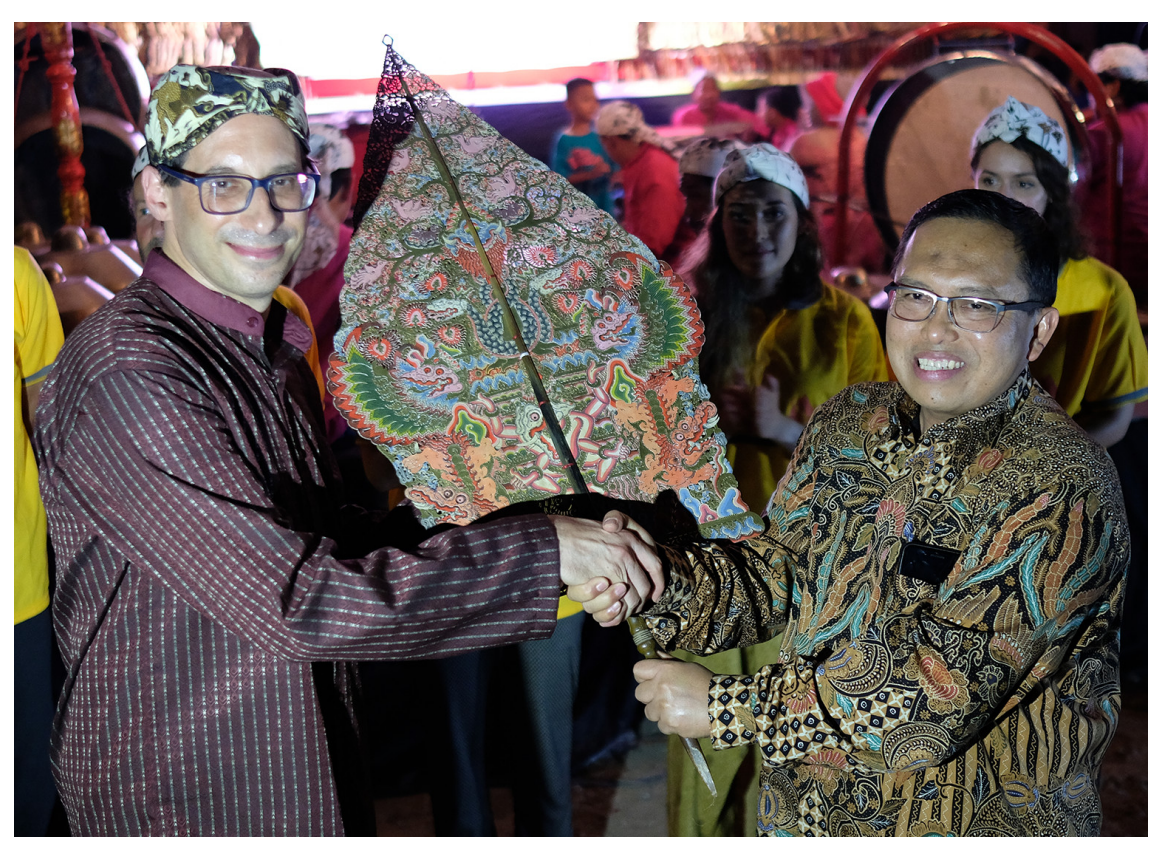

FIGURE 3 Puppeteer Matthew Cohen (left) being ceremonially handed a kayon puppet by Maulana Najmudin, director of cultural diplomacy in the Ministry of Education and Culture (right), during a ministry-sponsored wayang kulit tour of Java's north coast. Photograph from 31 July 2018, courtesy of the Ministry of Education and Culture

ded by the Indonesian government. Since 2015, the Ministry of Education and Culture has been awarding Indonesia Cultural Awards (Penghargaan Kebudayaan) in the Foreign Individual (Perorangan Asing) category to leading international arts and humanities scholars in an annual ceremony that also recognizes Indonesian 'maestros', artistic innovators, creative communities, supportive local governments, and other individuals and groups. Lesser honours are bestowed at more local-level events. So, for example, at the International Gamelan Festival held in London in 2017, three of the founding figures of the British gamelan scene (composer Alec Roth, ethnomusicologist Neil Sorrell, and producer Anne Hunt) received awards from the Ministry of Education and Culture.

Breaking a decades-long cycle of relationship dependency in which Indonesian artists and artistic institutions expected handouts from foreign sources, the ministry is funding Indonesianists in international collaborations. A recent example is a wayang kulit tour of Java's north coast I undertook with gamelan musicians from the United Kingdom and Cirebon (West Java, Indonesia) (Figure 3$)$. 
This was the result of a proposal by the Indonesian embassy of London's cultural attaché Professor E. Aminudin Aziz, and involved the participation of the local puppeteer union of Cirebon and local governments at the kabupaten and kotamadya levels. The tour took our company to Cirebon's palaces, an ancestral shrine in Brebes, an isolated fishing village in Karawang, a city park in Purwakarta, and the city of Tegal's gigantic central square, among other locations. Performances were in the Cirebon dialect of Javanese and highlighted the vibrancy of Cirebon's distinctive shadow puppet theatre through interweaving references to contemporary issues including the Me Too movement and debates around foreign rectors in Indonesian universities. Each performance was preceded by short dances by local dance companies, a battle demonstration by an award-winning teenage puppeteer from Cirebon, and short speeches by local officials and ministry personnel. The tour was heavily featured in local media. Hundreds came to watch, meet, and take selfies with the performers from Britain, drawing new audiences to a traditional art and demonstrating new possibilities for international cooperation to villagers and urbanites. The tour sparked an interest in Cirebon among the British gamelan players, who intend to teach the new skills they learned through collaborating with Cirebon musicians to their students in the UK.

Most important has been the establishment of a sub-directorate for cultural diplomacy in the Kementerian Pendidikan dan Kebudayaan (Ministry of Education and Culture) in 2013. ${ }^{14}$ This was initially formed as a reaction to the cultural wars between Indonesia and Malaysia, which raged between 2007 and 2012, over the proprietorship of tangible and intangible cultural properties including batik, Balinese dance, reog pageantry, and the folk song Rasa Sayange. The ministry expressed concern that many cultural properties had already been 'stolen, lost or claimed by outside parties' (dicuri, hilang, atau diakui pihak lain), taking this as a sign of Indonesia's weakness in the area of cultural diplomacy (Kementerian Pendidikan dan Kebudayaan 2015:48). The establishment of the sub-directorate has enabled a coordinated, strategic approach to arts diplomacy, with an emphasis on facilitating, documenting, and providing logistical support for collaborative grass-roots, sustainable projects that combine the work of Indonesian and overseas artists, and local governmental bodies and foreign institutions.

14 The sub-directorate was initially part of the Direktorat Internalisasi Nilai dan Diplomasi Budaya (Directorate of Internalization of Values and Cultural Diplomacy), founded in 2013, and then moved to the Direktorat Warisan dan Diplomasi Budaya (Directorate of Cultural Heritage and Diplomacy), established in a 2015 reorganization of the ministry. 
This collaborative, networked approach is enabled by a set of laws for the advancement of culture enacted in 2017 (Undang-Undang Republik Indonesia Nomor 5 Tahun 2017 Tentang Pemajuan Kebudayaan). According to clause 43 of these laws, in addition to ensuring freedom of expression, maintaining artistic diversity, curating knowledge about the arts, ensuring the sustainability of cultural ecosystems and other such internal goals, the central government has a mission to 'use culture as a medium of international diplomacy' and 'increase international cooperation in the cultural field'.

Two recently established programmes explicitly formulated for arts diplomacy are Rumah Budaya (Cultural Houses, established in 2014) and the cultural platform Indonesiana (established in 2018). The first initiative is a network of cultural institutes similar in design and function to the British Council, Goethe Institute, and the French Institute, organizations that have done much in Indonesia over the decades to promote the latest thinking on the arts, sustain cosmopolitan art practices, and promote cultural exchange. Indonesia's Cultural Houses similarly aim to be a public space for cultural exchange to increase appreciation for, and build cooperation in, the arts and culture.

The Indonesiana programme, still in its first year of operation when this article was written, is establishing, funding, and managing a suite of national and international festivals, involving visiting artists and companies along with local governments, building on Indonesia's experience of Europalia and other such platforms. Nine festivals, located in five different islands of Indonesia, are planned for the second half of 2018 under the Indonesiana banner, including the monumental International Gamelan Festival, with hundreds of gamelan musicians and experts flying into the central Javanese city of Solo from around the world, to the rather more modest weaving festival in North Tapanuli, Sumatra, which aims to restore the sacred values of a local weaving tradition.

The practice of Indonesian arts diplomacy is changing very rapidly. At a conference held as recently as 2014, American performance curator Judy Mitoma, who ran one of the most important cultural exchange programmes between the us and Asia in the 199os, 'expressed hopes that in the future, Indonesian cultural diplomats would find funds within Indonesia, thereby becoming freer to express Indonesian culture without the constraints of foreign influence' ( $\mathrm{Cul}$ tural Diplomacy 2014:4). Since the creation of a sub-directorate for cultural diplomacy, funds for projects under the banner of arts diplomacy are now more easily found in Indonesia than in most countries. But that is not to say that Indonesia is free from 'the constraints of foreign influence'. Rather, we have seen a fusion of horizons, in which Indonesian agents strive not to awe foreigners with impressive displays of skills, but instead seek to establish sustainable structures for cooperation, collaboration, and exchange. 
A comprehensive accounting of Indonesian arts diplomacy is impossible, such is the complexity of agency (with many coordinating bodies and contributing individuals involved in any given event); the global geographic spread of diplomatic sites; the variability in duration (a performance abroad lasting a few minutes, a lifetime of teaching and performing gamelan internationally); the combination of formal public presentations with informal, private exchanges; and the diverse channels of impact (business investment, inspiring a holiday in Bali, international treaties). This attempt to periodize arts diplomacy by identifying prevalent organizational structures and strategies, presentational modes and diplomatic rationales can only, at best, provide comparators and contexts for diplomatic aspects of international arts events. There is no way to survey the whole, nor calculate the overall efficacy of this field of practice. This article emphasizes cultural productions I have seen and participated in during my years of living in Western Europe, the United States, and Indonesia-but there are many more, both near and far from me, that have escaped my attention. Even the Sub-Directorate for Cultural Diplomacy, which aims to monitor, encourage, and implement arts diplomacy, can hardly claim full knowledge or a monopoly on the practice. Recent large-scale arts diplomatic events such as the Frankfurt Book Fair, Europalia, and the International Gamelan Festival involved necessarily multiple government agencies and drew on the expertise of individual experts and non-governmental organizations. ${ }^{15}$ The American-born publisher, editor, and translator John McGlynn, for example, has played a massive role in the promotion of Indonesian literature internationally, including the organization of Indonesian participation in recent book fairs of note. Arts diplomacy is rarely, if ever, an autonomous practice, but depends on metacultural infrastructure (cf. Urban 2001) to travel through the world.

Any study of a global phenomenon such as arts diplomacy is limited and enabled by the vantage point of the observer. For Prijono, who oversaw arts diplomacy during the late Sukarno period as the minister of basic education and culture, the cultural exchanges that 'counted' in the early 196os were those with countries with signed cultural agreements with Indonesia, namely Malaya, the Philippines, India, the United Arab Republic, the Democratic Republic of Vietnam, China, Bulgaria, Romania, Pakistan, Cuba, Iraq, Hungary, Czechoslovakia,

15 I would like to thank one of the anonymous reviewers of this article for this important point. 
and the USSR (Prijono 1964:4). There was of course much Indonesian arts activity going on in countries not favoured by Sukarno-including pasarmalam cultural fairs in the Netherlands, initiated in 1956 by the cultural activist and writer Jan Boon (better known under his pen name Tjalie Robinson), and gamelan study in American universities, commenced by Mantle Hood at UCLA in $195^{8}$. But these international cultural sites were not under Prijono's direct purview and not conceived as arts diplomacy at the time.

Performance scholar Diyah Larasati (2013), who participated in Soeharto-era cultural missions as a dancer, chafes against patriarchal domination in international tours, the process of 'screening' and indoctrination that performers were subjected to (especially arduous for her due to family connections to communism), the co-option of folk art forms which were once liberatory sites of popular protest, the instrumentalization of sacred dances for 'the nation-state's propaganda and economic stimulus machine' (Larasati 2013:54) and performances which purportedly 'proffer a more spiritual, essential, or "human" engagement and knowing' but actually are offered to hide 'underlying governmental transaction' (Larasati 2013:121).

Larasati (2013:134) is quite correct in arguing that

[c]ultural export is frequently performed in order to establish a new diplomatic relationship or expand an existing one, which then translates into economic cooperation between a sending and a host country. The idea is that by promoting culture in a way that is focused on beauty in connection with a sense of peaceful harmony, investors or major donor countries will feel safer in pursuing stronger economic ties. (Performance of traditional arts also functions as a particular political, economic tool: dances appear to reveal the 'human side' of state representatives and their national traditions, playing on the desires of donor nations to know their Others and possibly fostering a sense of emotional attachment that may extend and strengthen future relations.)

But this desire for the Other, which has been a core factor in international performances of Indonesia since the nineteenth century (cf. Cohen 2010; Spiller 2015), is often a starting point for deeper and more ethical engagements. Larasati's own touring as a dancer in cultural missions provided a stock of experiences and skills that ultimately contributed to her successful academic career based in the United States, where she is able to both represent and critique Indonesia in consort with like-minded reflexive collaborators.

A recent example of such work is her danced response to Dadang Christanto's solo exhibition MISSING at its opening at the Wei-Ling Gallery in Kuala 
Lumpur in 2018. The central work in this show is a wall of 110 portraits representing in rough charcoal the heads of people who went missing in the Indonesian genocide of 1965-1966. Larasati, dressed in an elegiac white robe, enters the space in the attitude of a classical Javanese dancer, with graceful arm movements that transform fluidly into a threatening martial-arts move and then exaggerated military marching, flailing, rubbing out invisible stains, and beckoning to ghosts, before a bow to the audience. ${ }^{16}$ In this way, she mediates between past and present, the disembodied and the corporeal, that which endures and that which vanishes. Her participation fuses horizons to remind us of ethical duties to the Other; her own complex positionality makes her a paradigmatic arts diplomat today.

\section{Acknowledgements}

Many thanks to Mark Hobart, who convened the panel 'How Indonesians Argue' at EuroSEAS in Oxford in 2017, where an early version of this article was presented; the Ministry of Education and Culture, which sponsored my wayang kulit (shadow puppet theatre) tour of Java in the summer of 2018, allowing for participant-observation research; the convenors of the Performance Studies Working Group at Yale University, to which a revised version of this article was offered in 2018; and the Yale Institute of Sacred Music, which hosted me as a Fellow in 2018-2019 and gave me the time and support to complete revisions.

\section{References}

Ang, Ien, Yudhishthir Raj Isar, and Phillip Mar (2015). 'Cultural diplomacy: Beyond the national interest?', International Journal of Cultural Policy 21-4:365-81.

Appiah, Kwame Anthony (1997). 'Cosmopolitan patriots', Critical Inquiry 23-3:617-39. Balme, Christopher B. (2007). Pacific performances: Theatricality and cross-cultural encounter in the South Seas. Basingstoke: Palgrave Macmillan.

Bloembergen, Marieke (2006). Colonial spectacles: The Netherlands and the Dutch East Indies at the world exhibitions, 1880-1931, translated by Beverley Jackson. Singapore: Singapore University Press.

16 Deborah Germaine Augustin, 'The vanishing'. https://pluralartmag.com/2018/10/27/the -vanishing/ (accessed 11-4-2019). 
Brown, Charles Cuthbert (1952). 'Sejarah Melayu or "Malay annals", A translation of Raffles MS 18', Journal of the Malaysian Branch of the Royal Asiatic Society 25-1:1276.

Brown, John (2006). 'Arts diplomacy: The neglected aspect of cultural diplomacy', in: William P. Kiehl (ed.), America's dialogue with the world, pp. 71-9o. Washington, DC: Public Diplomacy Council.

Caute, David (2003). The dancer defects: The struggle for cultural supremacy during the Cold War. Oxford: Oxford University Press.

Chalmers, John H. Jr. (1986). 'The first international gamelan festival and symposium', Balungan 2-3:3-16.

Coast, John (1953). Dancers of Bali. New York: Putnam.

Cohen, Matthew Isaac (2010). Performing otherness: Java and Bali on international stages, 1905-1952. Basingstoke: Palgrave Macmillan.

Cohen, Matthew Isaac (2013). 'Indonesian performing arts in the Netherlands, 19131944', in: Bart Barendregt and Els Bogaerts (eds), Recollecting resonances: Indonesian-Dutch musical encounters, pp. 231-58. Leiden: Brill.

Cohen, Matthew Isaac (2016). Inventing the performing arts: Modernity and tradition in colonial Indonesia. Honolulu, H I: University of Hawai'i Press.

Cohen, Matthew Isaac and Laura Noszlopy (2010). 'Introduction: The transnational dimension in Southeast Asian performance', in: Laura Noszlopy and Matthew Isaac Cohen (eds), Contemporary Southeast Asian performance: Transnational perspectives, pp. 1-23. Cambridge: Cambridge Scholars Publishing.

Cultural diplomacy (2014). Cultural diplomacy: Rising soft power in emerging markets. 2014. Los Angeles: Usc Center on Public Diplomacy at the Annenberg School. [CPD Annual Research Conference 2014 conference report.] http://uscpublicdiplomacy .org/sites/uscpublicdiplomacy.org/files/useruploads/u2015o/EmergingMarketsPD .pdf (accessed 3 October 2018).

Dhaimeler, Didier Hamel (2007). Theo Meier, 1908-1982: A Swiss artist under the tropics. Jakarta: Hexart.

Diamond, Jody (1986). [Untitled opening editorial], Balungan 2-3:1.

Fabian, Johannes (1999). 'Theater and anthropology, theatricality and culture', Research in African Literatures 30-4:24-31.

Foley, Kathy (1992). 'Trading art(s): Artaud, Spies, and current Indonesian/American artistic exchange and collaboration', Modern Drama 35-1:10-19.

Forbes, Cameron (2007). Under the volcano: The story of Bali. Melbourne: Schwartz.

Geertz, Clifford (1991). 'The year of living culturally', New Republic 205-17:30-6.

Gillitt, Cobina Asmara (1991). 'New York's Festival of Indonesia: Shifting the "normative expectation"', TDR 35-1:19-21.

Gillitt, Cobina Asmara (2017). 'Rachel Cooper', Asian Theatre Journal 34-1:16987 . 
Goldstein, Joshua (1999). 'Mei Lanfang and the nationalization of Peking Opera, 19121930', positions: east asia cultures critique 7-2:377-420.

Hughes-Freeland, Felicia (1989). 'Indonesian image enhancement', Anthropology Today $5^{-6: 3-5 .}$

Ingham, Sue (2014). 'Defining the nation?', Inside Indonesia 115. http://www.insideindo nesia.org/defining-the-nation-2, accessed 13 June 2019.

Kementerian Pendidikan dan Kebudayaan (2015). Peta jalan reformasi birokrasi 20152019. Jakarta: Kementerian Pendidikan dan Kebudayaan. http://repositori.perpustak aan.kemdikbud.go.id/4802/1/RB\%2oKemendikbud\%2O2O15-2O19\%2orev\%2OZ\%2 o29Okt20015\%2BCover.pdf, accessed 15 August 2018.

Khrushchev, Sergei (ed.) (2013). Memoirs of Nikita Khrushchev. Vol. 3: Statesman, 19531964. University Park, PA: Pennsylvania State University Press.

Kusuma-Atmadja, Mochtar (1987). 'Diplomasi kebudayaan, diplomasi perjuangan', Horison 21-5:329-33.

Larasati, Rachmi Diyah (2013). The dance that makesyou vanish: Cultural reconstruction in post-genocide Indonesia. Minneapolis: University of Minnesota Press.

Lindsay, Jennifer (2012). 'Performing Indonesia abroad', in: Jennifer Lindsay and Maya HT Liem (eds), Heirs to world culture: Being Indonesian, 1950-1965, pp. 191-220. Leiden: KITLV Press.

Lopez y Royo, Alessandra (2008). 'Indonesian dance performance in Britain: Transnational futures?', in: Urmimala Sarkar Munsi (ed.), Dance, transcending borders, pp. 199-214. New Delhi: Tulika Books.

McIntosh, Jonathan (2009). 'Indonesians and Australians playing Javanese gamelan in Perth, Western Australia: Community and the negotiation of musical identities', The Asia Pacific Journal of Anthropology 10-2:80-97.

Mendonça, Maria (2002). Javanese gamelan in Britain: Communitas, affinity and other stories. [PhD thesis, Wesleyan University.]

Noszlopy, Laura (2014) 'The "little legong dancers" of Bali: The rise of a child star in Indonesian dance theater', in: Gillian Arrighi (ed.), Entertaining children: The participation of youth in the entertainment industry, pp. 167-84. New York: Palgrave Macmillan.

Park, Sang Mi (2006). 'The making of a cultural icon for the Japanese Empire: Choe Seung-hui's U.s. dance tours and "new Asian culture" in the 1930s and 1940s', positions: east asia cultures critique 14-3:597-632.

Pink, Peter (1996) 'The last wayang performance sponsored by Sukarno', in: Clara Brakel-Papenhuijzen (ed.), Performing arts of Asia: The performer as (inter) cultural transmitter, pp. 69-78. Leiden: International Institute for Asian Studies.

Prijono (1964). 'Politik pendidikan dan kebudajaan Dep. P.D. dan K.', Pewarta P.P.K. 121/2:1-4.

Rosser, Andrew (2001). The politics of economic liberalization in Indonesia: State, market and power. Richmond: Curzon. 
Sankey, Charlotte (1989). 'Tribal art show masks government hypocrisy', Spare Rib 203 (July):58.

Shimazu, Naoko (2014). 'Diplomacy as theatre: Staging the Bandung conference of 1955', Modern Asian Studies 48-1:225-52.

Spiller, Henry (2010). Erotic triangles: Sundanese dance and masculinity in West Java. Chicago: University of Chicago Press.

Spiller, Henry (2015) Javaphilia: American love affairs with Javanese music and dance. Honolulu, Hi: University of Hawai'i Press.

Steijlen, Fridus (2015). 'Indo-European pasar malam, identity and performance in the Netherlands', in: Barbara Hatley (ed.), Performing contemporary Indonesia: Celebrating identity, constructing community, pp. 203-20. Leiden: Brill.

Stevens, Alan M. and A. Ed. Schmidgall-Tellings (2004). A comprehensive IndonesianEnglish dictionary. Athens, он: Ohio University Press.

Supardi, Nunus (2013). Bianglala budaya: Rekam jejak 95 tahun kongres kebudayaan 1918-2013. Jakarta: Direktorat Jenderal Kebudayaan, Kementerian Pendidikan dan Kebudayaan.

Suzuki, Masae (2016). 'Interlude: Okinawan theatre: Boundary of Japanese theatre', in: Jonah Salz (ed.), A history ofJapanese theatre, pp. 150-4. Cambridge: Cambridge University Press.

Taylor, Charles (1994). 'The politics of recognition', in: Amy Gutmann (ed.), Multiculturalism: Examining the politics of recognition, pp. 25-73. Princeton: Princeton University Press.

Thornbury, Barbara E. (2013). America's Japan and Japan's performing arts: Cultural mobility and exchange in New York, 1952-2011. Ann Arbor: University of Michigan Press.

Urban, Greg (2001). Metaculture: How culture moves through the world. Minneapolis: University of Minnesota Press.

Von Eschen, Penny M. (2004). Satchmo Blows up the World:Jazz Ambassadors Play the Cold War. Cambridge, MA: Harvard University Press.

Wallis, Brian (1994). 'Selling nations: International exhibitions and cultural diplomacy', in: Daniel J. Sherman and Irit Rogoff (eds), Museum culture: Histories, discourses, spectacles, pp. 265-81. London: Routledge. [First published in 1991.]

Warsito, Tulus and Wahyuni Kartikasari (2007). Diplomasi kebudayaan: Konsep dan relevansi bagi negara berkembang; Studi kasus Indonesia. Yogyakarta: Ombak.

Wasilewski, Jessica L. (2017). 'Effecting dynamic cultural exchange through the performing arts: Three case studies of U.s. exchanges with Asia: Festival of Indonesia in Performance (1990-1992), Dance: The Spirit of Cambodia (1991), Season of Cambodia (2013)'. [MA thesis, Wesleyan University.]

Wenten, I Nyoman (1996). The creative world of Ki Wasitodipuro: The life and work of a Javanese gamelan composer. [PhD thesis, University of California, Los Angeles]. 
Wilcox, Emily (2017). 'Performing Bandung: China's dance diplomacy with India, Indonesia, and Burma, 1953-1962', Inter-Asia Cultural Studies 18-4:518-39.

Williams, Louise Blakeney (2007). 'Overcoming the "contagion of mimicry": The cosmopolitan nationalism and modernist history of Rabindranath Tagore and W.B. Yeats', The American Historical Review 112-1:69-100.

Yuan, Zhenjie, Junwanguo Guo, and Hong Zhu (2016). 'Confucius Institutes and the limitations of China's global cultural network', China Information 30-3:334-56. 